\title{
INDUSTRIAL RELATIONS: COMPARATIVE NON-STANDARD EMPLOYMENT RELATIONSHIP IN NIGERIA AND INDONESIA
}

\author{
Devi Melisa Damiri* dan Mohammad Benny Alexandri ** \\ * Magister Business Administration, Padjadjaran University \\ **Graduate lecturer - Department of Business Administration Science \\ Faculty of Politics and Social Science, Padjadjaran University \\ Email :devimelisadamiri@gmail.com, bennyalexandri@yahoo.co.id
}

\begin{abstract}
The research objective is to study and determine the level of non-standard employment relationships in Nigeria and Indonesia. The employment relationship is not as standard as is initial workers, which are contract employees and outsourcing. The nonstandard employment relationship are reinforced by the number of unemployment in Nigeria and Indonesia which are every form of nonstandard employment will offer the challenge but it will tend to have the great of losses.The results of the study found that non-standard employment relationships in Nigeria and Indonesia in general is not different. Most employees are not standard work is in positions which have low skills, without a career path and can harm the development of human resources for both companies or clients.
\end{abstract}

On the other hand, who had a temporary job as an employee or non-standard employee is better than not having a job. Therefore the unemployment rate can be reduced and can significantly increase the country's economic growth.

Keywords: Unemployement, nonstandard employment relations, contract employees, outsourcing, country's economic growth

\section{HUBUNGAN INDUSTRIAL: PERBANDINGAN HUBUNGAN KERJA TIDAK STANDAR DI NEGARA NIGERIA DAN INDONESIA}

\begin{abstract}
ABSTRAK
Penelitian ini bertujuan untuk mempelajari dan menentukan tingkat hubungan kerja tidak standar di Nigeria dan Indonesia. Hubungan kerja tidak standar yang dimaksud sebagai karyawan kontrak dan outsourcing. Hubungan kerja tidak standar diperkuat oleh jumlah pengangguran yang ada di Nigeria dan Indonesia dimana setiap bentuk pekerjaan tidak standar menawarkan tantangan namun akan cenderung memiliki banyak kerugian. Hasil penelitian ditemukan bahwa hubungan kerja tidak standar di Nigeria dan Indonesia pada umumnya tidak berbeda. Sebagian besar karyawan merupakan pekerja tidak standar yang memiliki keterampilan kerja yang rendah, tanpa memiliki jenjang karir dan dapat membahayakan perkembangan sumber daya manusia baik bagi perusahaan maupun klien. Di sisi lain, memiliki pekerjaan sementara baik sebagai pekerja standar ataupun pekerja tidak standar akan lebih baik daripada tidak memiliki pekerjaan. Dengan demikian tingkat pengangguran dapat dikurangi dan secara signifikan dapat meningkatkan pertumbuhan ekonomi negara.

Kata kunci: Pengangguran, hubungan kerja tidak standar, karyawan kontrak, outsourcing, pertumbuhan ekonomi negara.
\end{abstract}




\section{PENDAHULUAN}

Globalisasi secara bersamaan memberikan dampak positif maupun negatif bagi suatu negara. Salah satu ciri penting globalisasi adalah dunia dan pasar kini terintegrasi dan terkoneksi satu sama lain ke dalam satu lingkungan, adanya kemungkinan masuknya pesaing-pesaing dari negara maju yang ikut berkompetisi dalam perekonomian liberal dunia dengan kekuatan perekonomian yang tentu saja pasti jauh lebih kuat. Era globalisasi menyebabkan beberapa perusahaan asing bermigrasi ke daerah-daerah di dunia terutama ke negara Nigeria, di mana biaya tenaga kerja dianggap lebih murah dibandingkan di negara asalnya. Di beberapa perusahaan di Nigeria sebagaian besar pekerja berada pada kategori pekerja lepas, kontrak dan outsourcing. Hal ini banyak dilakukan perusahaan asing dengan tujuan untuk meminimalkan biaya tenaga kerja dan meningkatkan keuntungan perusahaan. Sebagian besar perusahaanperusahaan tersebut beroperasi tanpa memperhatikan standar ketenagakerjaan yang mengatur masing-masing negara. Isu-isu yang muncul terkait hubungan kerja tidak standar diperburuk dengan banyaknya jumlah pengangguran secara besar-besaran di negaranegara Afrika (Okafor, 2012).

Hubungan kerja tidak standar tidak hanya terjadi di negara Nigeria saja, bahkan di negara Indonesia yang memiliki sumber daya manusia berlimpah mengalami hal tersebut. Berdasarkan data statistik dari ILO (ILO, 2015) bahwa pasar tenaga kerja di Indonesia terus mengalami perkembangan selama tahun 2014 dan 2015, di mana partisipasi kerja mengalami pertumbuhan sedangkan pengangguran terbuka mengalami penurunan. Pertumbuhan tersebut tidak terlepas dari penggunaan pekerja tidak standar, masih banyak perusahaan di Indonesia yang menggunakan agen perekrutan dalam memenuhi kebutuhan SDM. Penggunaan outsourcing di Indonesia semakin meluas ke berbagai lini kegiatan perusahaan hanya saja tidak menempati posisi bisnis inti perusahaan.
Setiap bentuk hubungan kerja tidak standar mungkin menawarkan tantangan tersendiri tetapi cenderung memiliki kerugian yang lebih besar, seperti sistem upah rendah, diskriminasi sistem pengupahan dan kesejahteraan, tidak ada keamanan kerja, tidak memiliki jenjang karir, maupun durasi kerja yang tidak pasti. Fenomena hubungan kerja tidak sesuai standar hingga kini masih terjadi di berbagai negara, khususnya di negara-negara berkembang. Hubungan kerja tidak standar tidaklah berarti memiliki dampak negatif bagi suatu negara, melainkan mampu memberikan dampak positif juga bagi pertumbuhan perekonomian suatu negara. Penulis tertarik untuk mempelajari dan mengetahui hubungan kerja dengan membandingkan hubungan kerja tidak standar di negara Nigeria dan Indonesia dengan tujuan mengetahui sisi positif dan negatif terhadap negara yang menerapkan hubungan kerja tidak sesuai standar ketenagakerjaan.

\section{TINJAUAN PUSTAKA}

\section{Globalisasi}

Sumber daya manusia menjadi salah satu kunci pembangunan suatu negara. SDM yang berkualitas sangat dibutuhkan, tidak hanya cerdas secara intelektual tetapi juga mempunyai keterampilan dan citra diri yang positif dalam menghadapi era globalisasi. Pengaruh globalisasi dapat menghilangkan berbagai halangan dan rintangan yang menjadikan dunia semakin terbuka dan saling bergantung satu sama lain. Globalisasi dapat dipahami sebagai perubahan-perubahan dalam bidang ekonomi dan sosial yang berkombinasi dengan pembentukan kesalinghubungan regional dan global yang unik, yang lebih ekstensif dan intensif dibandingkan dengan periode sebelumnya, yang menantang dan membentuk kembali komunitas politik, dan secara spesifik, negara modern (Held 2000). Dengan perubahan tersebut ikut meningkatkan investasi asing dan menciptakan peluang kerja di negara-negara berkembang seperti Nigeria dan Indonesia. 


\section{Pengangguran}

Pengangguran adalah suatu keadaan di mana seseorang yang tergolong dalam angkatan kerja ingin mendapatkan pekerjaan tetapi belum dapat memperolehnya (Sadono, 2000). Pengangguran adalah tren global, tetapi kebanyakan terjadi pada negara di dunia berkembang, dengan petugas sosial, konsekuensi ekonomi, politik, dan psikologis. Isu hubungan kerja tidak standar telah menjadi masalah sangat umum di organisasi kerja, sebagai akibat dari globalisasi dan situasi pasar tenaga kerja yang tidak stabil di Nigeria. Sejak tahun 1999 dalam kasus di Nigeria, setelah dilakukan demokratisasi politik dan kepentingan pemerintah federal baru dalam pelaksanaan kebijakan neoliberal, pelaksanaan hubungan kerja tidak sesuai standar telah terjadi peningkatan di berbagai organisasi kerja (Adenugba, 2003; Adewumi, 2008; Onyeonoru, 2004, 2008).

Pengangguran adalah masalah makroekonomi yang mempengaruhi manusia secara langsung dan merupakan yang paling berat. Bagi kebanyakan orang, kehilangan pekerjaan berarti penurunan standar kehidupan dan tekanan psikologis. Jadi tidaklah mengejutkan jika pengangguran menjadi topik yang sering dibicarakan dalam perdebatan politik dan para politisi sering mengklaim bahwa kebijakan yang mereka tawarkan akan membantu menciptakan lapangan kerja (Gregory Mankiw, 2003).

\section{Hubungan Kerja Tidak Standar}

Kecenderungan perusahaan menerapkan hubungan kerja tidak standar lebih besar daripada pekerja standar atau dapat disebut karyawan tetap. Pekerja tidak standar termasuk pekerja kontrak sementara, pekerja kontrak, pekerja lepas, dan juga karyawan outsourcing. Tipe tenaga kerja dalam hubungan kerja tidak standar seperti yang digunakan dalam penelitian ini merujuk kepada pekerja lepas, pekerja kontrak atau sementara waktu dan outsourcing (Ferber and Waldfogel, 1998; Kalleberg, 2000). Meskipun ketiga kategori tersebut tidaklah sama, namun mereka semua memiliki hak yang terbatas di perusahaan tempatnya bekerja. Dalam bidang ketenagakerjaan, outsourcing diartikan sebagai pemanfaatan tenaga kerja untuk memproduksi atau melaksanakan suatu pekerjaan oleh suatu perusahaan, melalui perusahaan penyedia jasa pekerja/buruh (Husni, 2014). Outsourcing adalah penyerahaan penerima pemborongan pekerjaan atau perusahaan penyedia jasa pekerja/buruh melalui perjanjian pemborong pekerjaan secara tertulis (Maimun, 2007).

Peningkatan hubungan kerja tidak standar terjadi secara global tidak hanya di negara berkembang. Karyawan tidak standar yang terjadi di negara Kanada mengacu pada pekerja paruh waktu, sementara penuh waktu atau biasa disebut kontrak, dan pekerjaan paruh waktu sementara. Hasil penelitian yang dilakukan Isik dan Gordon (2008) menunjukkan bahwa sebagian besar perusahaan di Kanada melakukan hubungan kerja sesuai standar (pekerjaan reguler penuh waktu), yaitu sebesar 83\%. Dengan proporsi paruh waktu sebanyak $12 \%$, sementara penuh waktu $2 \%$, dan pekerjaan paruh waktu sementara 3\%. Pada hubungan kerja tidak standar, gender perempuan cenderung lebih memiliki peluang karir lebih tinggi. Dalam angkatan kerja berjenis kelamin laki-laki hanya yang berstatus sebagai pekerjaan paruh waktu sementara saja yang cenderung memiliki peluang karir untuk dipromosikan oleh perusahaan. Bekerja sebagai pekerja reguler paruh waktu atau kontrak tidak berdampak pada peluang karir untuk pekerja laki-laki. Secara keseluruhan menunjukkan bahwa ketiga jenis hubungan kerja tidak standar tidak mempengaruhi promosi bagi pekerja perempuan, akan tetapi untuk pekerja laki-laki promosi berpengaruh bagi mereka yang bekerja sebagai paruh waktu sementara. Pemerintah nasional di Afrika berupaya untuk menarik lebih banyak investasi asing dan tidak menerapkan standar perburuhan yang ketat (Adewumi, 2008). Telah ada kesepakatan substansial, akan tetapi karyawan dalam tiga kategori ini tetap 
rentan terhadap dinamika pasar tenaga kerja dan mendapatkan manfaat yang lebih sedikit jika dibandingkan dengan karyawan biasa. Bagi Negara, sistem outsourcing juga menjadi penyebab bagi tingginya tingkat perselisihan hubungan industrial. Perselisihan hubungan industrial dapat timbul karena perbedaan kesejahteraan antara pekerja outsourcing dan bukan outsourcing meskipun dalam satu perusahaan dengan tingkat pekerjaan dan tugas yang sama (Ross \& Bamber 2009). Abraham dan Taylor (1996) menemukan bahwa mempekerjakan karyawan tidak tetap dapat menghemat biaya, perusahaan mengatakan hanya ada sedikit alasan untuk membayar karyawan dengan upah yang tinggi, serta karyawan tidak tetap lebih mudah untuk diganti.

Hubungan kerja tidak standar yang terjadi di Uni Eropa merujuk pada pekerja kontrak jangka tetap, kontrak paruh waktu, on-call kontrak, outsourcing, kontrak freelance dan sejenisnya. Dalam Cremers (2010) bahwa tahun 2005 pekerja paruh waktu di Uni Eropa meningkat menjadi $18 \%$ dengan didominasi oleh perempuan, Hampir sepertiga perempuan yang bekerja sebagai pekerja paruh waktu dibandingkan dengan laki-laki hanya $7 \%$. Karyawan sesuai standar meningkat dari $12 \%$ pada tahun 1998 kini menjadi lebih dari 14\% pada tahun 2005. Hubungan kerja tidak standar yang terjadi tentu saja memberikan ketidakamanan bagi pekerja dengan rendahnya jaminan pendapatan, kualitas kerja rendah, keterbatasan akses pendidikan, kesehatan dan kondisi hidup dasar lainnya.

Pekerja tidak standar dan ketidakamanan kerja bukan hal baru bagi angkatan kerja di negara Jepang. Penelitian yang dilakukan Gottfried (2008) bahwa angka dari pekerja tidak standar di Jepang relatif tinggi, khususnya di kalangan perempuan. Proporsi pekerja sementara meningkat terutama pada perempuan, hal ini disebabkan oleh peningkatan pekerja paruh waktu dan kontrak jangka tetap.Pekerjaan tidak standar berarti bahwa pekerja yang memiliki sedikit syarat untuk mendapatkan perlindungan dan memiliki risiko ekonomi yang tidak pasti. Pekerjaan tidak standar mencerminkan pangsa kuantitatif lebih besar dari total lapangan kerja dan menandai pergeseran kualitatif dalam harapan tentang peraturan yang mengatur hak kontraktual, risiko dan tanggung jawab yang menyimpang dari norma-norma (Gottfried, 2008). Pengusaha di Jepang yang menerapkan hubungan kerja tidak standar bertujuan untuk menghindar dari regulasi atau norma-norma hukum yang berkaitan dengan jaminan keamanan bagi pekerja. Studi kasus Jepang menunjukkan bahwa kekuatan serikat (density), sistem intermediasi (coordinated vs bilateralisme) dan tingkat interaksi antara serikat pekerja dan pengusaha (sentralisasi/desentralisasi) berdampak pada kualitas pekerjaan tidak standar melalui lembaga penetapan upah, pelaksanaan standar perburuhan dan peraturan yang mengatur hubungan kerja. Disamping itu, munculnya hubungan kerja non standar dapat mengancam keamanan ekonomi yang lebih besar dari jumlah pekerja. Dengan memperluas prinsip perlakuan yang sama antara pekerjaan standar dan tidak standar akan meningkatkan kondisi kerja secara keseluruhan.

Pada dasarnya pekerja tidak standar memiliki persamaan di setiap negara, kategori pekerja tidak standar di Korea Selatan merujuk pada pekerjaan paruh waktu, pekerja sementara melalui lembaga (outsourcing), kontraktor independen dan sejenisnya. Menurut Korea National Statistical Office (KNSO, 2012), pada tahun 2003 jumlah pekerja tidak standar sebanyak 4,6 juta pekerja dan pada 2012 meningkat sebanyak 23\%, menjadi 6 juta pekerja. Penelitian yang dilakukan Lee Bokim (2013) menemukan bahwa pada pekerja tidak standar terdapat ketidakpuasan dalam hal pekerjaan dan kehidupan. Masalah yang terjadi di Korea Selatan adalah pengusaha rela mengganti pekerja standar (karyawan tetap) dengan pekerja tidak standar. Hal ini disebabkan karena pekerja tidak standar dibebaskan dari hukum dan kebijakan yang melindungi karyawan, pekerja tidak standar dapat dengan 
mudah diberhentikan dan upah pekerja tidak standar yang lebih murah dari pekerja standar. Dalam Jee Young, et al (2016) bahwa pekerja tidak standar lebih mungkin untuk berada ke dalam kategori pekerja miskin, karena upah yang rendah. Pasar tenaga kerja tidak standar mencakup pekerja usia muda yang memiliki sedikit kesempatan untuk dipekerjakan. Dengan mengurangi perbedaan upah antara pekerja standar dan tidak standar dapat meningkatkan kesempatan bagi pekerja untuk pindah menjadi pekerja standar. Dengan demikian memungkinkan pekerja untuk meningkatkan produktivitas, komitmen pekerja di tempat kerja, mengurangi ketidakpuasan pekerja serta ketidakstabilan pekerjaan. Sedangkan menurut Andrew Eungi dan Innwon Park (2006) perubahan tren pekerjaan yang terjadi di Korea Selatan berlaku terhadap gender, umumnya pekerja laki-laki lebih baik daripada rekan pekerja perempuan. Dalam periode pasca krisis keuangan, pekerja perempuan menghadapi diskriminasi dalam hal perekrutan dan promosi. Dua faktor yang menyebabkan meningkatkan jumlah dan proporsi pekerja tidak standar Korea, yaitu tingkat pengangguran yang tinggi di tengah krisis keuangan sehingga memaksa banyak orang untuk mencari pekerjaan sementara atau tidak standar, serta tidak adanya undang-undang dan peraturan yang melindungi hak-hak pekerja tidak standar. Undang-undang ketenagakerjaan yang ada di Korea Selatan cenderung untuk memenuhi kepentingan pengusaha atau perusahaan dibandingkan kepentingan pekerja tidak standar, contohnya hukum yang memungkinkan pengusaha untuk mempekerjakan pekerja paruh waktu atau pekerja sementara untuk pekerjaan biasa dan terus menerus. Restrukturisasi neoliberal Korea memungkinkan perusahaan-perusahaan untuk secara terbuka mempekerjakan lebih banyak pekerja sementara dan paruh waktu dan mengembangkan sistem diperluas subkontrak produksi.

Berdasarkan penelitian yang dilakukan oleh McLaughlin dan Alisha (2008) pekerjaan tidak standar di area nonmetropolitan Amerika Serikat banyak dikaitkan dengan kualitas yang lebih rendah pekerjaan dan terbatas atau pekerjaan yang tidak mendapat manfaat kesehatan atau pensiun, tidak memiliki komitmen kerja jangka panjang. Selain itu, manfaat dan upah kerja yang diterima oleh pekerja tidak standar lebih rendah daripada pekerja standar. McLaughlin dan Alisha (2008) berhipotesis bahwa prevalensi hubungan kerja tidak standar akan lebih tinggi di daerah nonmetro dan pekerjaan tidak standar akan lebih sering terjadi pada setiap industri dan kategori pekerjaan di nonmetropolitan dari wilayah metropolitan. Pekerja sebagai operator, perakit, pekerjaan buruh, dan terkait dengan pekerja yang membutuhkan sedikit keterampilan berada pada level hubungan kerja yang tidak standar. Hubungan kerja tidak standar lebih disukai oleh pekerja yang ingin memiliki waktu kerja lebih fleksibel dalam mengontrol pekerjaan dan dalam menyeimbangkan peran pekerjaan dan keluarga.

Pertumbuhan lapangan kerja tidak standar menjadi fenomena internasional yang menarik perhatian penelitian secara signifikan, selanjutnya penulis akan membandingkan hubungan kerja tidak standar yang terjadi di Taiwan. Hubungan kerja tidak standar dipandang sebagai faktor penyebab perubahan perilaku organisasi dan sikap antara berbagai tipe pekerja, sehingga mengakibatkan pola interaksi baru. Berdasarkan data survei yang dilakukan Roger dan Yvonne (2013) dari total 1.182 berstatus sebagai karyawan, dengan jumlah pekerja reguler penuh waktu sebesar $68,8 \%$, reguler paruh waktu $0,8 \%$, wiraswasta $12,8 \%$, dan pekerja tidak standar sebesar $17,6 \%$. Pasar tenaga kerja di Taiwan telah mengalami perubahan yang sama dalam dekade terakhir, banyak organisasi-organisasi yang mempekerjakan pekerja tidak standar atau pengurangan karyawan dalam upaya untuk menurunkan biaya dan meningkatkan daya saing. Organisasi yang menerapkan hubungan kerja tidak standar menimbulkan dampak yang signifikan dan negatif terhadap kepuasan kerja 
karyawan. Hasil penelitian yang dilakukan Kapsalis dan Pierre (2004) bahwa 6 dari 10 pekerja di Kanada sebagai pekerja permanen, pekerja penuh waktu, dan bentuk pekerja standar, sedangkan sisanya adalah pekerja paruh waktu, pekerja sementara, atau wiraswasta. Pada tahun 2001, sekitar 38\% dari seluruh pekerja Kanada adalah pekerja tidak standar, sebesar $15 \%$ bekerja sebagai pekerja sementara, $14 \%$ sebagai wiraswasta, dan 9\% sebagai pekerja paruh waktu permanen. Konsekuensi ekonomi dari pekerjaan tidak standar sangat tergantung pada situasi kerja jangka pendek atau jangka panjang. Di samping itu, pekerja tidak standar hanya sedikit yang menerima manfaat asuransi kerja, selain pekerja penuh waktu sementara (kontrak) yang sebagian darinya menerima manfaat tersebut. Kekhawatiran mengenai hubungan kerja tidak standar timbul karena pekerja dalam pekerjaan ini cenderung memiliki penghasilan rendah dan lebih mungkin untuk hidup dalam keluarga berpenghasilan rendah pula. Hubungan kerja tidak standar adalah cara umum memasuki pasar tenaga kerja. Beberapa pengusaha atau perusahaan mempekerjakan pekerja sementara, paruh waktu dalam memenuhi kebutuhan sumber daya manusia di perusahaannya dan tidak sedikit pada akhirnya perusahaan menawarkan hubungan kerja standar bagi pekerja tidak standar yang memiliki kinerja baik.

Di negara Cina mayoritas peningkatan jumlah pekerja tidak standar adalah pekerja yang berasal dari suatu agen atau lembaga. Li dan Chen (2012) dalam Xueli Wang, et al (2014) bahwa jumlah total pekerja agen (outsourcing) lebih dari 60 juta, sebesar 20\% dari seluruh pekerja di Cina. Perusahaan yang mempekerjakan pekerja agen dapat mengurangi biaya dan meningkatkan efisiensi dan fleksibilitas, akan tetapi dapat menimbulkan tantangan besar bagi staf manajemen perusahaan. Xueli Wang, et al (2014) pun mengatakan bahwa untuk meningkatkan komitmen organisasi pekerja lembaga atau agen, maka manajemen harus peka terhadap persepsi keadilan perusahaan bagi pekerja dan perlu untuk memahami arti pentingnya pekerjaan mereka sebagai pekerja tidak standar. Beberapa pengusaha di Cina telah mencapai hasil yang lebih baik dengan memotivasi pekerja tidak standar. Misalnya, Shanghai Zhenhua Port Mesin Co, Ltd (ZPMC) mempekerjakan sejumlah besar karyawan sebagai pekerja lembaga, perusahaan tidak hanya menyediakan pekerjaan yang baik, kondisi hidup tetapi juga memperhatikan motivasi pekerja tidak standar dengan menyediakan jalur pengembangan karir, kehormatan dan penghargaan, tunjangan tambahan berdasarkan tingkat keterampilan, dan klub yang diorganisir. Dengan komitmen organisasi yang tinggi mampu membantu ZMPC untuk menduduki tiga perempat dari pasar pelabuhan crane tingkat dunia.

\section{METODE PENELITIAN}

Penelitian ini dilakukan dengan melihat dari data sekunder, data tersebut diambil dari berbagai penelitian terdahulu, studi kepustakaan seperti buku dan jurnal yang berkaitan dengan hubungan kerja tidak standar pada kedua negara, Nigeria dan Indonesia. Data tersebut mencakup mengenai kondisi pasar tenaga kerja, hubungan kerja tidak standar hingga hokum ketenagakerjaan yang mengatur di kedua negara. Kemudian setelah dilakukan pengumpulan data, data tersebut akan diolah dan dianlisis secara deskriptif. Analisis secara deskriptif ini dilakukan agar data dapat digambarkan secara jelas mengenai perbedaan atau persamaan yang ada pada kedua negara. Whiting (1964) mengatakan bahwa "Description emerges following the creative exploration, and helps to arrange the findings in an order that will helpto be fit for explanations and these explanations can then be tested to validate the variablesbeing studied and withthe aid of description, knowledge is illuminated and facts that were ignored can now be brought to light and better understood'.

\section{HASIL DAN PEMBAHASAN}

\section{Situasi Pasar Tenaga Kerja dan Hubungan Kerja Tidak Standar di Nigeria}

Pasar tenaga kerja Nigeria tidak hanya jenuh tetapi juga ditandai dengan banyak pengangguran 
kaum muda berbagai bentuk seperti musiman, gesekan, perputaran dan pengangguran struktural (Okafor, 2012). Tingkat kompetisi tidak hanya berskala nasional tetapi sudah pada skala internasional, dengan demikian SDM perlu memiliki daya saing, ketrampilan maupun keahlian. Berdasarkan data statistik dari Badan Tenaga Kerja dan Statistik Biro Federal (2010) dalam Awogbenle and Iwuamadi (2010), menunjukkan bahwa Nigeria memiliki populasi kaum muda sebesar 80 juta penduduk dengan jumlah $60 \%$ mewakili dari total populasi negara Nigeria. Juga, 64 juta dari penduduk Nigeria adalah pengangguran, sementara sebanyak 1,6 juta penduduk memiliki pekerjaan. Dalam hal usia, pendidikan dan jenis kelamin, data yang diberikan oleh Biro Statistik Nasional (2010) menunjukkan lebih lanjut bahwa pada bulan Maret 2009 di Nigeria, untuk antara usia 15 dan 24 tahun 41,6\% adalah pengangguran, usia antara 25 dan 44 tahun sebesar $17 \%$ adalah pengangguran. Dan penduduk dengan lulusan sekolah dasar sebanyak 14,8\% pengangguran, penduduk dengan lulusan sekolah menengah $23,8 \%$ adalah pengangguran. Selanjutnya, untuk pendidikan menengah atas sebesar $21,3 \%$ pengangguran, tidak sekolah sebesar $21 \%$ dan lainnya $22,3 \%$. Tidak ada kecenderungan yang konsisten dari tingkat pengangguran di Nigeria. Pengangguran Nigeria dapat dikelompokkan menjadi dua kategori (Oyebade, 2003), yaitu pengangguran yang lebih tua yang kehilangan pekerjaan melalui penghematan atau kebangkrutan dan pengangguran dari kalangan usia muda, yang sebagian besar belum pernah bekerja.

Sebagian pekerja tidak standar memiliki beragam latar belakang pendidikan di berbagai bidang seperti teknik, ilmu komputer, telekomunikasi dan akuntansi. Hubungan kerja standar dapat didefinisikan sebagai karyawan fulltime, kerja terus menerus di mana karyawan bekerja pada suatu perusahaan berada di bawah pengawasan pimpinan. Aspek utama dari hubungan ini meliputi; kontrak kerja berdurasi waktu tidak terbatas (tetap), standar jam kerja per minggu dengan manfaat sosial yang cukup. Di beberapa perusahaan di Nigeria sebagaian besar karyawan berada pada kategori pekerja lepas, kontrak dan outsourcing. Hubungan kerja semacam ini dapat menyebabkan pengurangan biaya operasional perusahaan dengan meningkatkan kemudahan menerima dan mengeluarkan karyawan dari perusahaan (Richardson dan Allen, 2001).

\section{Situasi Pasar Tenaga Kerja dan Hubungan Kerja Tidak Standar di Indonesia}

Pasar tenaga kerja di Indonesia terus mengalami perkembangan selama tahun 2014 dan 2015, di mana partisipasi kerja mengalami pertumbuhan sedangkan pengangguran terbuka mengalami penurunan. Indonesia saat ini dalam tahap pembangunan di mana memiliki jumlah penduduk usia kerja yang lebih tinggi dibandingkan penduduk usia tua yang mandiri (ILO, 2015). Tenaga kerja dengan latar belakang pendidikan yang tinggi dapat menikmati upah yang lebih besar dan kesempatan kerja yang lebih baik. Berdasarkan data dari Badan Penelitian Statistik (2015) bahwa Tingkat pengangguran pada Agustus 2015 diperkirakan sebesar 6,2\% dan angka ini tergolong tinggi bila dibandingkan periode-periode sebelumnya. Tabel berikut memperlihatkan meluasnya pengangguran di Indonesia di tahun 2015, dengan tingkat partisipasi angkatan kerja sebesar $65,8 \%$. Akan tetapi bila dillihat dari tahun sebelumnya, tingkat pengangguran cukup mengalami penurunan di tahun 2013 hingga Februari 2015. Hal ini menunjukkan pertumbuhan yang cukup baik. 
Tabel 1. Indikator Penting Pasar Tenaga Kerja (2013-2015)

\begin{tabular}{|lcccccc|}
\hline \multicolumn{1}{c}{ Variabel } & Feb & Agt & Fob & Agt & Feb & Agt \\
& 2013 & 2013 & 2014 & 2014 & 2015 & 2015 \\
\hline Angkatan kerja (juta) & 123,6 & 120,2 & 125,3 & 121,9 & 128,3 & 122,4 \\
\hline $\begin{array}{l}\text { Pekerja (juta) } \\
\text { Pengangguran (juta) }\end{array}$ & 116,4 & 112,8 & 118,2 & 114,6 & 120,6 & 114,8 \\
\hline $\begin{array}{l}\text { Tingkat partisipasi } \\
\text { angkatan kerja }\end{array}$ & $69,2 \%$ & $66,8 \%$ & $69,2 \%$ & $66,6 \%$ & $69,5 \%$ & $65,8 \%$ \\
\hline $\begin{array}{l}\text { Tingkat pengangguran } \\
\text { P, }\end{array}$ & $5,8 \%$ & $6,2 \%$ & $5,7 \%$ & $5,9 \%$ & $5,8 \%$ & $6,2 \%$ \\
\hline
\end{tabular}

Sumber : Pasar Tenaga Kerja Indonesia, BPS (2015) Jakarta

Permintaan akan pekerja dengan kualifikasi tinggi melampaui suplai tenaga kerja yang ada. Suplai tenaga kerja yang berlebihan untuk mereka yang memiliki latar belakang pendidikan SMK dan SLTA Umum.

Tabel 2. Tingkat pengangguran berdasarkan pendidikan

\begin{tabular}{|c|c|c|c|c|}
\hline Sentoi & ${ }_{2014}^{\mathrm{Feb}}$ & $\frac{\mathrm{Ag}}{2014}$ & $\frac{\mathrm{Fab}}{2015}$ & Agit \\
\hline SD atau kurane & 3,69 & 3,04 & 3.61 & 2.74 \\
\hline SMP & 7,44 & 7.15 & 7.14 & 5,22 \\
\hline SMA & $9,1 n$ & 9,55 & 8.17 & 10,37 \\
\hline SMK & 7,21 & 11,24 & 9,05 & 12,65 \\
\hline Bipioma VI1/II & 5,87 & 6,11 & 7,10 & 7,54 \\
\hline Universites & 4,31 & 5,65 & 5,34 & 5,40 \\
\hline Junilah cereanequran & 5,70 & 5.94 & 5,81 & 5,18 \\
\hline
\end{tabular}

Sumber : Pasar Tenaga Kerja Indonesia, BPS (2015) Jakarta

Tingkat pendidikan Diploma sebesar 7,54\% dan lulusan Universitas sebesar 6,40\%. Tingkat pengangguran yang masih tinggi di kalangan lulusan SMA ini menunjukkan pentingnya upaya pemerintah ataupun perusahaan untuk mendorong terciptanya lapangan pekerjaan ataupun lembagalembaga pelatihan.

Gambar 1. Status Pekerjaan, tahun 2006 - 2015

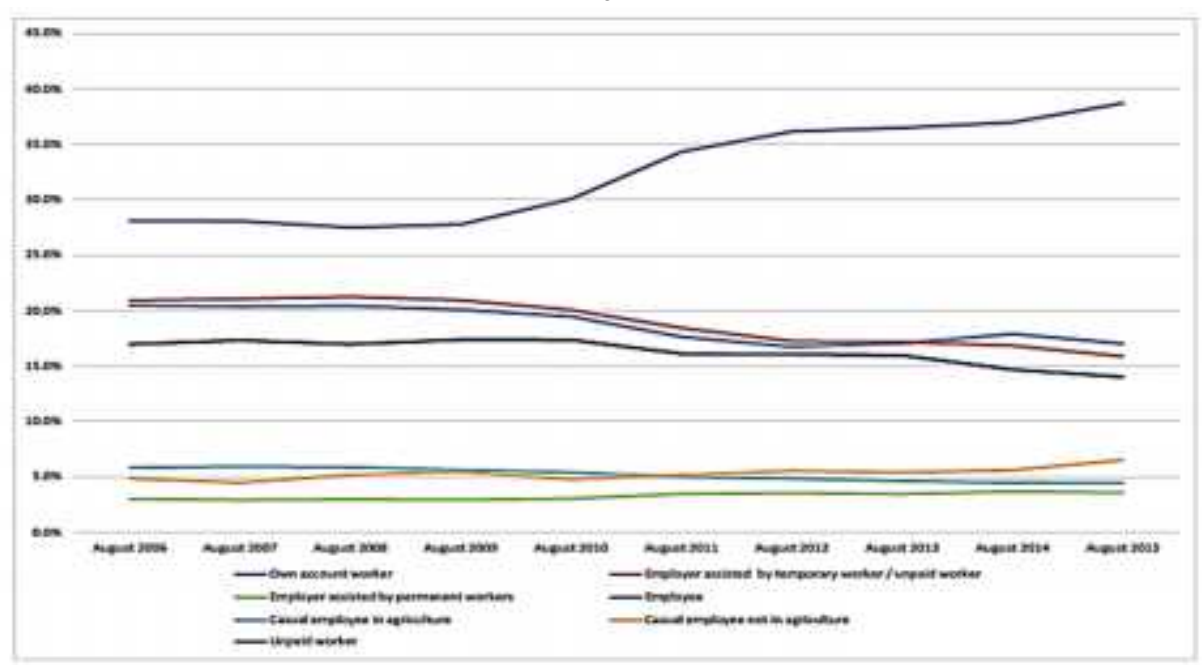

Sumber : Pasar Tenaga Kerja Indonesia, BPS (2015) Jakarta dalam ILO 
Tren-tren pertumbuhan terus berlanjut untuk status karyawan tetap, periode Agustus 2015 sebesar 38,7 persen dari mereka bekerja sebagai karyawan tetap. Dengan peningkatan jumlah penduduk yang bekerja sebagai karyawan tetap, maka karyawan tidak standar mengalami penurunan. Pada tahun 2006 sebesar 68,9\% pekerja dianggap sebagai pekerja yang terlibat dalam pekerjaan tidak sesuai standar, sementara pada 2015 angka ini berkurang menjadi 57,8\%. Meski tren pertumbuhan mengalami kenaikan atas karyawan tetap, akan tetapi jika dilihat dari grafik tersebut bahwa karyawan tidak sesuai masih tergolong tinggi di Indonesia.

Kecenderungan beberapa perusahaan untuk memperkerjakan tenaga kerja tidak standar, saat ini di Indonesia umumnya dilatarbelakangi oleh strategi perusahaan untuk melakukan efisiensi biaya produksi. Hal ini tidak jauh berbeda dengan yang dialami negara Nigeria. Perusahaan berusaha untuk menghemat pengeluaran dalam membiayai Sumber Daya Manusia (SDM) yang bekerja di perusahaan. Pekerja tidak standar seperti karyawan kontrak, pekerja lepas, outsourcing umumnya memiliki kualitas hidup lebih rendah dibandingkan karyawan standar, mengalami ketidakamanan kondisi keuangan, ketidakmampuan untuk merencanakan masa depan dan sering mengalami tekanan emosional dan psikologis. Tenaga kerja yang terlibat dalam hubungan kerja tidak standar biasanya memiliki beban kerja hampir sama atau bahkan lebih berat daripada pegawai tetap, namun dari segi gaji atau fasilitas lainnya berbeda. Praktek hubungan tenaga kerja tidak standar tidak sepenuhnya memberikan banyak keuntungan bagi karyawan yang menjalaninya, hal penting seperti jenjang karir, jaminan kesehatan, jaminan pensiun, masa kerja yang tidak dapat diprediksikan menjadi masalah yang selalu dihadapi. Di sisi lain perusahaan yang menerapkan sebagian besar hubungan tidak standar dapat memberikan kerugian bagi perusahaan. Karyawan yang bekerja akan cenderung tidak memiliki komitmen yang tinggi sehingga kinerja yang diberikan pun akan tidak maksimal, kualitas pendidikan rendah dan perusahaan tidak menyadari akan pentingnya SDM sebagai aset perusahaan. Kewajiban perusahaan dengan memberikan pelatihan dan pengembangan bagi seluruh SDM yang dimiliki, dengan demikian karyawan memiliki ketrampilan, keahlian, kemandirian maupun kreativitas untuk mengembangkan perusahaan menjadi semakin maju.

\section{Konsep Sistem Ekonomi}

Salah satu bentuk liberalisasi perdagangan yang berkembang diwadahi dalam World Trade Organisation (WTO) dengan neoliberalisme sebagai ideologi utamanya (Paulus, 2014). Munculnya lapangan kerja tidak sesuai standar ketenagakerjaan yang terjadi di Ngeria berkaitan juga pada teori neo-liberal (Okafor, 2012). Secara konseptual, neo-liberalisme mengacu pada keinginan untuk mengintensifkan dan memperluas pasar. Kebijakan neoliberal sukses mengurangi inflasi dan mendorong pertumbuhan ekonomi di beberapa negara. Neoliberalisme adalah ideologi ekonomi-politik yang terbukti semakin memperbesar jurang antara si kaya dan miskin. Konsep ekonomi Neoliberalisme berdasar dari sistem ekonomi, kapitalisme yang mengandalkan secara penuh perputaran roda ekonomi melalui mekanisme pasar bebas serta perpindahan modal secara bebas di dalam negeri maupun antar negara (pasar global). Sementara itu, kebijakan pasar bebas menyebabkan meningkatnya pengangguran sehingga meningkatkan tingkat kemiskinan di Afrika. Di sebagian besar negara, pengaruh ini telah mengakibatkan prevalensi hubungan kerja tidak standar dan dengan kenaikan ekstensi dalam pekerjaan tidak tetap (Okafor, 2012).

Negara Indonesia menganut konsep Demokrasi Ekonomi, dimana sistem perekonomian nasional yang merupakan perwujudan dari falsafah Pancasila dan UUD 1945 yang berasaskan kekeluargaan dan kegotongroyongan dari, oleh dan untuk rakyat dibawah pimpinan dan pengawasan pemerintah. Demokrasi ekonomi atas dasar asas 
kekeluargaan dengan demikian kemakmuran tidak hanya untuk individu atau kelompok melainkan semua orang. Demokrasi ekonomi yang ditegaskan dalam Pasal 33 ayat 4 UUD 1945 dilaksanakan dengan prinsip kebersamaan, efisiensi berkeadilan, berkelanjutan dan berwawasan lingkungan, kemandirian serta dengan menjaga keseimbangan, kemajuan dan kesatuan ekonomi nasional (Winarno, 2005).

\section{Hukum Ketenagakerjaan}

Hukum perburuhan yang berlaku di Nigeria memiliki perbedaan antara pekerja standar dan pekerja yang tidak sesuai standar dalam hal hak dan kesempatan. Dalam hukum yang berlaku menetapkan bahwa tidak ada organisasi yang dapat mempekerjakan karyawan tidak tetap selama lebih dari 90 hari tanpa membuatnya menjadi karyawan permanen atau tetap. Akan tetapi kenyataanya masih saja banyak perusahaan yang melakukan pelanggaran hukum. (Uvieghara, 2000; Ogundare dan Elia, 2011).

Karyawan tidak tetap dalam perusahaan biasanya akan dipekerjakan untuk periode singkat dari beberapa minggu, atau sampai dengan periode tiga bulan (dalam kasus Nigeria), sehingga mereka tidak mungkin mencapai status karyawan tetap. Karyawan kontrak, pekerja lepas, outsourcing umumnya memiliki kualitas hidup lebih rendah dibandingkan dengan karyawan sesuai standar, ketidakamanan kondisi keuangan, ketidakmampuan untuk merencanakan masa depan dan sering mengalami tekanan emosional dan psikologis. Selain itu, mereka tidak memiliki serikat buruh dan perlindungan di bawah Undang-Undang Ketenagakerjaan dan ketika mengalami konflik kepentingan antara perusahaan dengan karyawan tidak memiliki perlindungan yang kuat secara hukum di Nigeria.

Outsourcing dalam regulasi ketenagakerjaan di Indonesia biasanya hanya mencakup tenaga kerja pada proses pendukung (non core business unit) atau secara praktek semua lini kerja bias dialihkan sebagai unit outsourcing. Hak-hak karyawan outsourcing dan karyawan kontrak adalah sama dengan tenaga kerja pada umumnya. Hak yang harus diperoleh oleh tenaga outsourcing harus sesuai dengan peraturanperaturan yang berlaku seperti UU Ketenagakerjaan Nomor 13 tahun 2003 (pasal 64, 65 dan 66), UU Keselamatan dan Kesehatan Kerja, UU Jaminan Sosial Tenaga Kerja, UU Serikat Pekerja/Serikat Pekerja dan keputusankeputusan menteri tenaga kerja dan Transmigrasi Republik Indonesia No.Kep.101/Men/VI/2004 Tahun 2004 tentang tata cara perjanjian perusahaan penyedia jasa pekerja/buruh dan kepmenakertrans No. 220/Men/X/2004 tentang syarat-syarat penyerahan sebagai pelaksanaan pekerjaan kepada perusahaan lain (Sihombing, 2012).

Perusahaan-perusahan yang menerapkan hubungan kerja tidak standar di Indonesia khususnya kontrak dan outsourcing, sering mengabaikan peraturan perundang-undangan yang belaku sehingga sering terjadi pelanggaran hak-hak pekerja tidak standar. Dalam penerapannya, banyak hal yang terjadi dengan memperlihatkan dampak yang merugikan pekerja tidak standar. Dari sisi perusahaan, penerapan hubungan kerja tidak standar sangat menguntungkan. Banyak alasan yang dikemukaan oleh para pemimpin perusahaan mengenai kebijakan penerapan ini, salah satunya dapat menghapuskan kewajiban perusahaan untuk membayar kompensasi atas hak buruh ketika dilakukan pemutusan hubungan kerja (PHK).

Dalam kaitannya dengan hubungan industrial, Pemerintah Indonesia berperan sebagai pelindung pekerja/karyawan. Peran tersebut perlu ditegakkan sesuai dengan Pancasila maupun UU yang mengatur hubungan perusahaan dengan karyawan. Karyawan yang terlibat dalam hubungan kerja tidak standar biasanya memiliki beban kerja hampir sama atau bahkan lebih berat daripada pegawai tetap, namun dari segi gaji atau fasilitas lainnya tentu saja sangat berbeda, Inspektorat pengawasan ketenagakerjaan memainkan peran penting 
dalam menegakkan UU ketenagakerjaan dan mewujudkan hak-hak di tempat kerja.

Beberapa konvensi ILO secara bertahap disejajarkan dengan ketentuan perundangundangan dibidang ketenagakerjaan dengan yang terdapat di negara-negara maju. Secara aturan pemerintahan Indonesia telah memberikan pengaturan yang lebih baik bagi pekerja walaupun belum memadai secara prakteknya dilapangan.

\section{SIMPULAN}

Hubungan kerja tidak standar yang terjadi di negara berkembang Nigeria dan Indonesia secara umum tidak jauh berbeda, bahkan di negara-negara maju pun masing terdapat hubungan kerja tidak standar. Beberapa fenomena yang terjadi bahwa hubungan kerja tidak standar banyak memberikan kerugian bagi pekerja, namun terdapat juga negara yang berhasil menerapkan dengan memotivasi karyawan dan mendapatkan kesuksesan. Sebagian besar tenaga kerja tidak standar bekerja di posisi yang memiliki keterampilan rendah dan tanpa jenjang karir serta pekerja tidak standar dapat merugikan pengembangan sumber daya manusia baik bagi perusahaan ataupun klien. Masih banyak pekerja yang memiliki latar belakang pendidikan yang rendah menempati posisi tersebut dan di upah lebih rendah dari upah minimum.

Kebijakan, perlindungan, upah minimum, pesangon, alihdaya (outsource) dan tunjangan jaminan sosial terkait erat satu sama lain dan penggunaan perundingan bersama masih terbatas dalam hal penerapannya. Dalam hukum yang berlaku di Nigeria bahwa pemerintah menetapkan tidak memperbolehkan organisasi yang dapat mempekerjakan karyawan tidak tetap selama lebih dari 90 hari tanpa membuatnya menjadi karyawan permanen atau tetap. Namun pada kenyataannya, banyak perusahaan di Nigeria yang mempekerjakan sebagian besar jumlah pekerjanya adalah pekerja tidak standar dengan jangka waktu lebih dari waktu 90 hari.
Tidak jauh berbeda dengan negara Indonesia, pemerintah pun telah banyak mengeluarkan UU, kebijakan dan peraturan-peraturan seperti UU Serikat Pekerja dan keputusan-keputusan menteri tenaga kerja yang melindungi pekerja tidak standar. Pada implementasinya antara negara Nigeria dengan Indonesia serupa, bahwa perusahaan di kedua negara sering mengabaikan peraturan yang belaku sehingga sering terjadi pelanggaran hak-hak bagi pekerja tidak standar. Fenomena tersebut menimbulkan ketentuan terkait upah dan kesejahteraan bagi pekerja tidak standar hanyalah sesuai dengan kontrak atau perjanjian yang dibuat oleh perusahaan secara sepihak, di mana perjanjian kontrak yang sering terjadi lebih memposisikan pekerja berada di pihak yang lemah.

Umumnya pada suatu perusahaan akan terdapat beberapa golongan pekerja, yaitu karyawan tetap, karyawan kontrak dan karyawan outsourcing. Pengelompokkan tersebut secara tidak langsung membawa efek stratifikasi maupun jarak terhadap perilaku sosial di antara kalangan pekerja dalam suatu perusahaan, sehingga menimbulkan implikasi negatif terhadap sesame pekerja khususnya bagi pekerja tidak standar. Selain menimbulkan efek stratifikasi, pekerja tidak standar yang berada di Nigeria dan Indonesia cenderung kurang memiliki jenjang karir yang baik demi meningkatkan kualitas hidup pekerja dan keluarganya. Masa kerja yang memiliki keterbatasan waktu menjadi hambatan dan menurunkan peluang bagi pekerja tidak standar mendapatkan promosi menjadi pekerja standar dengan karir yang lebih aman dan menjanjikan. Pada praktiknya perusahaan di Nigeria dan Indonesia menjadi cenderung eksploitatif karena adanya perbedaan hak yang didapatkan oleh pekerja tidak standar. Padahal bila dibandingkan banyak dari tugas pekerjaan, beban kerja, tanggung jawab dan kewajiban para pekerja tidak tetap yang sama besarnya dengan para pekerja standar, jam kerja yang sama, dan bekerja di tempat yang sama pula. Penerapan hubungan kerja tidak standar tidak sepenuhnya 
dapat menguntungkan bagi perusahaan, melainkan dapat memberikan kontribusi negatif bagi perusahaan yang sebagian besar karyawannya merupakan pekerja tidak standar.

Dari sisi pekerja bahwa hubungan kerja tidak standar tidak dapat memberikan jenjang karir yang pasti sehingga menimbulkan rendahnya komitmen serta kinerja yang tidak optimal, selain itu tingkat turn over cenderung tinggi. Meskipun begitu tidak semua perusahaan di kedua negara memberi perlakuan berbeda terhadap pekerja tidak standar. Masih terdapat perusahaan-perusahaan yang memberikan jenjang karir bagi pekerja tidak standar dengan melakukan penilaian kerja dan merekomendasikan pekerja yang memiliki hasil kinerja yang optimal. Sumber daya manusia sebagai aset paling penting dalam suatu perusahaan, oleh karena itu karyawan perlu diberikan pelatihan, pengembangan, serta jenjang karir agar dapat memberikan manfaat bagi kedua belah pihak. Peningkatan kinerja karyawan secara perorangan akan mendorong kinerja sumber daya manusia secara keseluruhan, yang direfleksikan dalam kenaikan produktivitas ataupun profit perusahaan.

Di sisi lain dalam hal apapun, memiliki pekerjaan sementara atau sebagai pekerja tidak standar lebih baik daripada tidak memiliki pekerjaan sama sekali. Tingkat pengangguran yang cenderung tinggi di kedua negara masih diperlukan banyaknya penciptaan lapangan pekerjaan. Dengan demikian mampu mengurangi tingkat pengangguran yang secara umum berada di tingkat usia muda. Apabila dikelola dengan baik dan benar hubungan kerja tidak standar mampu meningkatkan kinerja dan efesiensi perusahaan, serta dapat meningkatkan kesejahteraan pekerja, perluasan lapangan kerja baru, membuka peluang yang sangat besar untuk masyarakat memiliki kesempatan kerja di perusahaan-perusahaan besar. Oleh karena itu ada baiknya pemerintah Nigeria maupun Indonesia perlu lebih dipertegas lagi mengenai mekanisme penyerahan pekerjaan kepada perusahaan lain (agen perekrutan). Hubungan kerja tidak standar seharusnya hanya boleh dilaksanakan untuk jasa cleaning service, keamanan, transportasi, ataupun katering. Berdasarkan hasil penelitian Xueli Wang, et al (2014) yang dilakukan di negara Cina, bahwa banyak pengusaha berhasil dengan sukses dalam menerapkan hubungan kerja tidak standar tanpa menghilangkan hak dan kewajiban yang seharusnya diberikan kepada pekerja tidak standar. Perusahaan dapat mengurangi biaya, meningkatkan efisiensi dan fleksibilitas, dan di sisi lain mempekerjakan sejumlah besar pekerja tidak standar (dalam hal ini adalah pekerja agen) dengan tetap memperhatikan kualitas hidup, memotivasi pekerja tidak standar, menyediakan jalur pengembangan karir, penghargaan, tunjangan tambahan berdasarkan tingkat keterampilan, sehingga kedua belah pihak berada dalam posisi yang sama-sama menguntungkan. Mengadopsi dari keberhasilan tersebut maka seharusnya semua pemangku kepentingan dalam kaitan hubungan industrial di Nigeria dan Indonesia perlu untuk mengembalikan fungsi inti manajemen sumber daya manusia untuk menghasilkan tenaga kerja lebih produktif dan efisien. Perlu dilakukan tindakan nyata bagaimana kebijakan dan peraturan pemerintah dapat bekerja sama dengan perusahaan-perusahaan yang menerapkan hubungan kerja tidak standar dalam melindungi pekerja serta menciptakan lapangan pekerjaan yang lebih banyak dan lebih baik. 


\section{DAFTAR PUSTAKA}

Abraham KG, dan Taylor SK. 1996. Firms' use of outside contractors: theory and evidence. J. Lab Econ., 14(3) : 394-424.

Adenugba AA. 2003. Globalisation and trade unionism in Nigeria: A case study of the Nigerian Labour Congress (NLC), A Ph.D. Pre-field Seminar Paper Presented to the Dept. of Socio., Uni. of Ibadan, Nigeria.

Adewumi F. 2008. Globalisation, Labour Standards and the Challenge of Decent Work in Nigeria. A paper presented at a Lecture organized by the MIPRSA, Socio. Dept., Uni. of Ibadan, Nigeria.

Awogbenle AC, Iwuamadi KC. 2010. Youth Unemployment:

Entrepreneurship

Development Programme As An Intervention Mechanism. Afr. J. Bus. Manage., 4(6) : 831-835.

Cremers, Jan. 2010. Non-standard employment relations or the erosion of workers' rights. Briefing Paper, 23. Solidar.

Eungi, Andrew., and Innwon Park. 2006. Changing Trends Of Work In South Korea. Asian Survey, Vol. 46, Issue 3 : 437-456.

Ferber M, Waldfogel J. 1998. The Long-Term Consequences Of Nontraditional Employment. Mon. Lab. Rev., 121(5) : 3-12.

Gottfried, Heidi. 2008. Pathways to Economic Security: Gender and Nonstandard Employment in Contemporary Japan. Soc Indic Res 88 : 179-196.

Held, David. 2000. "Regulating Globalization? The Reinvention Politics". International Sociology, 15(2) : 394-408.

Husni, Lalu. 2014. Pengantar Hukum Ketenagakerjaan Indonesia Edisi Revisi 12. Rajagrafindo Persada : Jakarta.

Kapsalis, Costa,. and Pierre Tourigny. 2004. Duration Of Non-Standard Employment. Perspective, Statistics Canada, Catalogue No. 75-001-XI.

Korea National Statistical Office. 2012. Economically active popula- tion survey. Seoul: Statistics Korea.

Lee, Bokim. 2013. Job and Life Satisfaction of Nonstandard Workers in South Korea. Workplace Health and Safety Vol. 61, No. 8.

Li, J., and Chen, H. 2012. Research Report Of Domestic Agency Workers. Beijing : AllChina Federation of Trade Unions.

Maimun. 2007. Hukum Ketenagakerjaan Suatu Pengantar. Pradnya Paramita : Jakarta.
Mankiw, N. Gregory. 2003. Makro Ekonomi, terjemahan Fitria Liza, Imam Nurmawan. Erlangga : Jakarta.

McLaughlin, Diane K., and Alisha J. 2008. Nonstandard Employment in the Nonmetropolitan United States. Rural Sociology 73 (4) : 631-659.

National Bureau of Statistics. 2009. Social Statistics in Nigeria. Abuja : The NBS Publication.

National Bureau of Statistics. 2010. Statistical News: Labour Force Statistics Abuja: The NBS Publication, p. 476.

Ogundare G, and Elijah S. 2011. The Oriental Ambush. National Standard, Feb. 10(5) : 1721.

Okafor, Emeka E. 2011. Emerging Nonstandard Employment Relations And Implications For Human Resource ManagementFunctions In Nigeria. Journal of Business Management Vol.6 (26) : 7612-7621.

Onyeonoru IP. 2004. Globalisation and Trade Union Resistance. Afr. J. Psych. Stud. Soc. Issues, 7(1): 45-50.

Onyeonoru IP. 2008. Labour Market in the Context of Economics Sociology: Bringing Society back to the Economy. Ibad. J. Soc. Sc. 6(1) : 55-67.

Oyebade SA. 2003. Education and Unemployment of Youths in Nigeria: Causes, Impacts and Suggestions. National Economic Empowerment Development Strategy (NEEDS) Document, p. 94.

Richardson S, and Allen J. 2001. Casualisation Of The Nursing Workforce: A New Zealand Perspective On An International Phenomenon. Int. J. Nurs. Pract., 7(2) : 104108.

Roger, Jyh-Jer., and Ying-Jung Yvonne. 2013. Worker Satisfaction Following Employment Restructuring: Effects of Nonstandard Workers and Downsizing on Job Satisfaction in Taiwan. Soc Indic Res, 110 : 453-467.

Ross and Bamber JG. 2009. Strategic Choice in Pluralist and Unitarist Employment Relation Regimes. A Studi of Australian Telecommunication. Industrial and Labor Relation Review.

Rudolf, Paulus. 2014. Masalah Globalisasi di Indonesia: Antara Kepentingan, Kebijakan, dan Tantangan. Jurnal Kajian Wilayah, Vol. 5, No. $1: 67-95$ 
Seong, Jee Young . et al. 2016. Work-related Attitudes of Non-regular and Regular Workers in Korea : Exploring Distributive Justice as a Mediator. Development And Society, Vol. 45, No. 1 : 39-67.

Sihombing, Jonker. 2012. Perlindungan Hukum Bagi Pekerja Di Indonesia Menurut Ketentuan Perundang-Undangan Yang Berlaku. Law Review Volume XII No. 1

Sukirno, Sadono. 2000. Makro Ekonomi Modern, Perkembangan Pemikiran dari Klasik Hingga Keynesian Baru. Raja Grafindo Persada : Jakarta.

Uvieghara EE. 2000. Labour Law in Nigeria. Lagos : Malthouse.

Wang, Xueli., et al. 2014. Transformational Leadership And Agency Workers' Organizational Commitment: The Mediating Effect Of Organizational Justice And Job Characteristics. Social Behavior And Personality 42(1) : 25-36.

Winarno, Roni. 2005. Penerapan Prinsip Demokrasi Ekonomi, Keadilan Dan Kepastian Hukum Dalam Hukum Penanaman Modal. Jurnal Perspektif Vol.X No.4.

Zeytinoglu, Isik U, dan Gordon B. Cooke. 2008. Non-Standard Employment And Promotions : A Within Genders Analysis. Journal of Industrial Relations, 50(2) : 319-33.

http://www.ilo.org/

https://www.bps.go.id/ 